J. Clin. Chem. Clin. Biochem.

Vol. 26, 1988, pp. 399-404

(C) 1988 Walter de Gruyter \& Co.

Berlin - New York

\title{
Enzymatic Colorimetric Method for the Determination of Inorganic Phosphorus in Serum and Urine
}

\author{
By G. Berti, P. Fossati, G. Tarenghi, C. Musitelli
}

Laboratorio Ricerca \& Sviluppo e Direzione Scientifica Miles Italiana SpA, Divisione Ames, Cavenago Brianza (Milano), Italia and

G. V. Melzi d'Eril

Laboratorio di Chimica-Clinica, IRCCS Policlinico S. Matteo, Pavia, Italia

(Received December 12, 1987/February 29, 1988)

Summary: The performance of an enzymatic colorimetric method for the determination of inorganic phosphorus in serum and urine is described. Phosphate ions react with inosine in the presence of purine nucleoside phosphorylase to form hypoxanthine; this is oxidized by xanthine oxidase to uric acid with production of hydrogen peroxide. The latter is determined with the aid of the chromogen system peroxidase/4-aminophenazone/N-ethyl-N-(3-methylphenyl)- $\mathrm{N}^{\prime}$-acetylethylenediamine, the coloured product being measured at $555 \mathrm{~nm}$. This series of reactions is completed in $5 \mathrm{~min}$ at $37^{\circ} \mathrm{C}$. The test is linear up to $240 \mathrm{mg} / \mathrm{l}$. Analytical recovery in serum averaged $101.2 \pm 1.2 \%$ and in urine $101.9 \pm 3.2 \%$. Within-run and between-run precision studies in serum and urine samples gave CVs $\leq 4.54 \%$ (at $22.0 \mathrm{mg} / \mathrm{l}$ ). Results obtained by this method agree $(r=\geq 0.983$ ) with the molybdate UV and molybdenum blue methods. Interference by endogenous substances, including organic phosphate, was negligible.

\section{Introduction}

Most techniques for the determination of inorganic phosphorus in serum or other biological fluids are based on phosphomolybdate complex formation by reaction of inorganic phosphate with molybdate in acid solution.

This colourless to pale yellow compound can be determined directly by UV absorption, or by colorimetric measurement after reduction to molybdenum blue or complexing with dyes such as malachite green (1).

These methods have several drawbacks: the direct UV method is affected by serum turbidity or pigmentation; the molybdenum blue method is influenced in its specificity, sensitivity and colour stability by the type of reducing agent used; and the strongly acidic conditions of the malachite green method may result in hydrolysis of organic phosphate.
All these methods are used nevertheless in the clinical laboratory, especially those based on direct procedures without deproteinization. Many attempts have been made to develop enzymatic methods: phosphorylase, phosphoglucomutase and glucose-6-phosphate dehydrogenase have been used to generate NADPH from inorganic phosphate and glycogen $(2,3)$. Glyceraldehyde-3-phosphate dehydrogenase was used as a key enzyme in an alternative enzymatic route leading to NADH (4). Hwang (5) reacts inosine with phosphate in the presence of purine nucleoside phosphorylase: $\left.{ }^{1}\right)$ the resulting hypoxanthine, in the presence of milk xanthine oxidase, ${ }^{1}$ ) produces uric acid, which is determined from its absorbance at $293 \mathrm{~nm}$.

') Enzymes:

Purine nucleoside phosphorylase (EC 2.4.2.1)

Xanthine oxidase (EC 1.1.3.22)

Peroxidase (EC 1.11.1.7) 
All these enzymatic methods, however, have various limitations such as the need for reading in the UV range; poor stability of substrates or enzymes; unfavourable reaction equilibrium; and laborious procedures. Significant developments have been reported by Fossati (6) and Machida (7), both using the Hwang enzymatic sequence. More precisely, Fossati assayed the superoxide ion (formed as hydrogen peroxide precursor during hypoxanthine oxidation) by reducing a tetrazolium salt to formazane; Machida assayed phosphate, likewise in the visible region, using the peroxidase/phenol/4-aminophenazone chromogen system with an appropriate microbial xanthine oxidase.

A fully enzymatic colorimetric method based upon the Machida enzymatic sequence has been recently described $(8,9)$.

The reaction is illustrated in figure 1: inorganic phosphate reacts with inosine in the presence of purine nucleoside phosphorylase (EC 2.4.2.1) to form hypoxanthine and ribose-1-phosphate. Hypoxanthine is then oxidized by xanthine oxidase (EC 1.1.3.22) to hydrogen peroxide and xanthine, which is in turn oxidized to uric acid with further production of hydrogen peroxide. The hydrogen peroxide thus formed reacts with the chromogen system 4-aminophenazone/ N-ethyl-N-(3-methylphenyl)-N'-acetylethylenediamine, in the presence of peroxidase (EC 1.11.1.7), to produce a purple-red dye.

In this paper we report in full the performance characteristics of this method for both serum and urine.

\section{Materials and Methods}

Apparatus

A double-beam spectrophotometer with temperature-controlled cuvette holder (Model Lambda 5, Perkin Elmer Corp., Norwalk, CT 06856) was used for all the spectrophotometric studies.

A CentrifiChem ${ }^{\circledR}$ System 400 (Baker Instruments Corp., Allentown, PA) was used for all the other studies.

\section{Reagents}

The reagent kit for the inorganic phosphate assay (SERAPAK ${ }^{\circledR}$ enzymatic colorimetric method, code 6683) was from Miles Italiana S.p.A., Ames Division, Cavenago Brianza (Italy).

The kit contains reagents to make two solutions in Pipes buffer $(20 \mathrm{mmol} / \mathrm{l}, \mathrm{pH} 6.25)$. Solution 1 contains $1.8 \mathrm{mmol}$ of $\mathrm{N}$-ethyl$\mathrm{N}$-(3-methylphenyl)- $\mathrm{N}^{\prime}$-acetylethylenediamine, $\geq 50 \mathrm{U}$ of xanthine oxidase, and $\geq 2400 \mathrm{U}$ of peroxidase per liter of Pipes. Solution 2 contains $1.3 \mathrm{mmol}$ of inosine, $\geq 50 \mathrm{U}$ of purine nucleoside phosphorylase, $\geq 70 \mathrm{U}$ of xanthine oxidase, $\geq 1200 \mathrm{U}$ of peroxidase, and $0.7 \mathrm{mmol}$ of 4-aminophenazone per liter of Pipes. Both solutions are stable for four weeks at $2-8^{\circ} \mathrm{C}$.

A "single working solution" can be prepared by mixing equal volumes of Solution 1 and 2 . Stored in a dark container protected from direct light, this solution will keep for three days at $2-8^{\circ} \mathrm{C}$ and for one day at $15-25^{\circ} \mathrm{C}$.

The kit also contains a calibration standard of potassium dihydrogen phosphate equivalent to $50 \mathrm{mg} / \mathrm{l}(1.61 \mathrm{mmol} / \mathrm{l})$ of inorganic phosphorus.

\section{Procedures}

Serum and diluted urine (1:10 with distilled water) were used as samples.<smiles>Oc1ncnc2c1ncn2[PbH]</smiles>
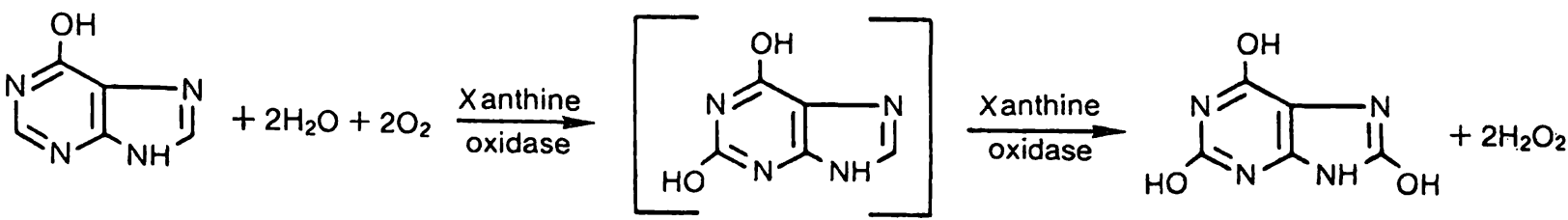<smiles>Cc1c(N)c(=O)n(-c2ccccc2)n1C</smiles><smiles>CCN(CCCNC(C)=O)c1cccc(C)c1</smiles><smiles></smiles><smiles>CC1=CCC=CC1=[IH]</smiles><smiles>CCN(C)C</smiles>

Fig. 1. Reaction sequence: enzymatic colorimetric assay of inorganic phosphate. 


\section{Manual two-step procedure}

Add $20 \mu \mathrm{l}$ of sample (or standard) to $1.5 \mathrm{ml}$ of Solution 1 , mix and incubate at $37^{\circ} \mathrm{C}$ for $2-5$ minutes. Add $1.5 \mathrm{ml}$ of Solution 2; mix and incubate 5 minutes at $37^{\circ} \mathrm{C}$, then read at $555 \mathrm{~nm}$ against the reagent blank. The results reported for the manual procedure were obtained by this method.

\section{Manual one-step procedure}

The assay can also be carried out as follows: add $20 \mu \mathrm{l}$ of sample (or standard) to $3.0 \mathrm{ml}$ of "single working solution", mix and incubate 5 minutes at $37^{\circ} \mathrm{C}$. Read at $555 \mathrm{~nm}$ vs the reagent blank.

\section{Automated procedure}

The following instrument setting was used for CentrifiChem: temperature $37^{\circ} \mathrm{C}$; wavelength $550 \mathrm{~nm}$; sample volume $5 \mu \mathrm{l}$, wash volume $55 \mu \mathrm{l}$; single working solution $350 \mu \mathrm{l}$; 1st reading time $3 \mathrm{~s}$; time interval $300 \mathrm{~s}$; control standard $50 \mathrm{mg} / \mathrm{l}$.

This procedure was validated by assaying 60 human sera by the automated procedure $(y)$ and by the manual one-step procedure $(x)$. Calculated linear regression was: $y=0.990 x+0.3$ $\mathrm{mg} / \mathrm{l}, \mathrm{r}=0.993, \mathrm{~S}_{\mathrm{yx}}=1.4, \overline{\mathrm{x}}=43.7, \overline{\mathrm{y}}=43.6$, range $20-80$ $\mathrm{mg} / \mathrm{l}$.

\section{Comparison methods}

For the UV method without deproteinization (10) we used the Inorganic Phosphorus Reagent kit from F. Hoffmann-La Roche $\&$ Co. Assays were made by the fixed-time technique on a CentrifiChem 400 system at $37^{\circ} \mathrm{C}$ with reading at $340 \mathrm{~nm}$.

For the molybdenum blue method with $p$-methylaminophenol sulphate as reducing agent (11) without deproteinization we used the Phosphorus Auto/Stat ${ }^{\circledR}$ Diagnostic kit from Lancer Division of Sherwood Medical (Ireland). Assays were made manually.

\section{Reference intervals}

Serum samples were taken from 152 adult blood donors $(75$ men and 77 women). The reference limits were determined by a non-parametric technique (12).

Twenty-four hour urine samples were collected from 48 healthy adults (19 men and 29 women). Because of the small number of samples, the reference limits were determined by parametric technique, after checking the Gaussian distribution.

\section{Control sera}

We used the following commercially available control sera: Monitrol (Merz \& Dade); Precinorm, Precilip (Boehringer Mannheim); Validate (General Diagnostics); Wellcomtrol (Wellcome); Ortho (Ortho); Roche (Roche); Kontrollogen (Behringwerke); Seronorm (Nyegaard); Biotrol (Biotrol); Q-Pak (Hyland).

\section{Results}

\section{Absorption spectrum}

The dye has an absorption peak at $555 \mathrm{~nm}$. The absorption spectrum is broad enough to allow measurements in the range of 540-560 nm without significantly affecting sensitivity.

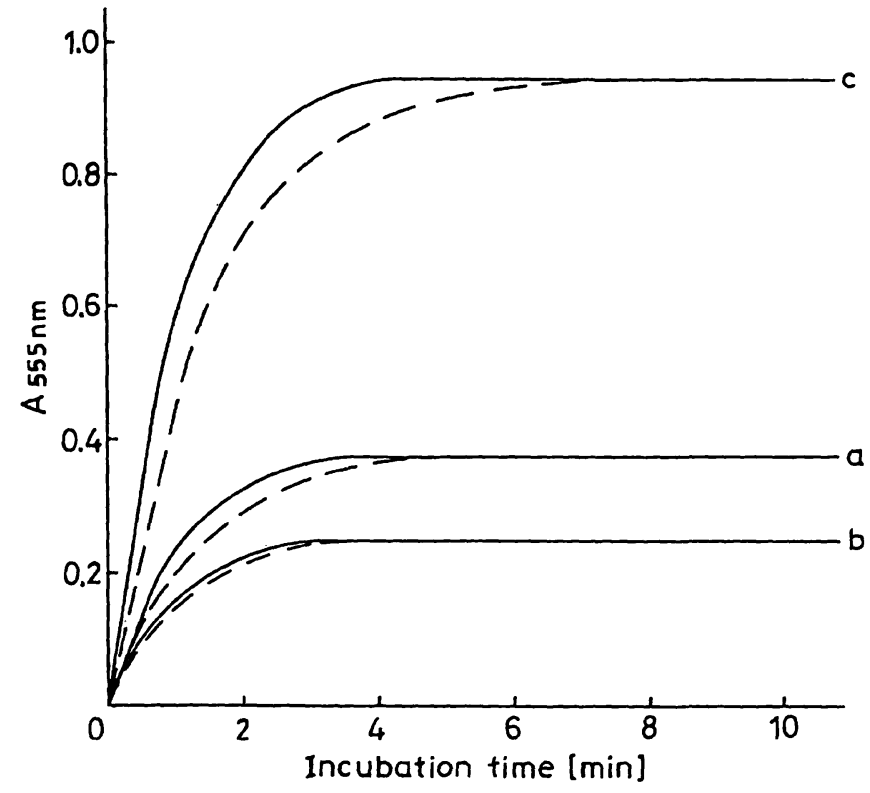

Fig. 2. Colour development curves at $20^{\circ} \mathrm{C}(---)$ and $37^{\circ} \mathrm{C}(-)$ for inorganic phosphorus standard at $50 \mathrm{mg} / \mathrm{l}$ (a), normal human serum (b), and abnormal human serum (c).

\section{Colour development}

We tested human sera and urines both normal and pathological for colour development rates. Complete colour development occurred within $5 \mathrm{~min}$ at $37^{\circ} \mathrm{C}$ or less than $10 \mathrm{~min}$ at room temperature $\left(18-25^{\circ} \mathrm{C}\right)$. Examples of colour development for aqueous inorganic phosphorus standard and human sera are shown in figure 2.

After the recommended incubation time, no significant colour changes were seen at room temperature for at least 2 hours.

\section{Linearity range and sensitivity}

We assessed (sample/reagent ratio of 1/150) method linearity and sensitivity with aqueous phosphate solutions. When net absorbance was plotted versus inorganic phosphorus concentration, the response proved linear up to $240 \mathrm{mg} / \mathrm{l}$ (regression equation $y=0.0758 x+0.007 ; r=0.9999)$.

Absorbance per $\mathrm{mg}$ of phosphorus (1 $\mathrm{cm}$ light path) is 0.076 , representing dye molar lineic absorbance of $1780 \mathrm{~m}^{2} \cdot \mathrm{mol}^{-1}$ at $555 \mathrm{~nm}$. For the CentrifiChem instrument, this requires a sample/reagent ratio of $1 / 80$; the linear range extends to $120 \mathrm{mg} / \mathrm{l}$.

\section{Recovery}

Recovery tests, made by spiking serum and urine pools with NBS potassium dihydrogen phosphate, gave (tab. 1) an average recovery of $101.2 \pm 1.2 \%$ (SD) for serum and $101.9 \pm 3.2 \%$ (SD) for urine. 
Tab. 1. Analytical recovery

\begin{tabular}{llcc}
\hline Sample & Added & Found & $\begin{array}{l}\text { Recovery } \\
(\%)\end{array}$ \\
\cline { 2 - 3 } & \multicolumn{1}{l}{ Inorganic phosphorus (mg/l) } & \\
\hline Serum pool & - & 37.6 & - \\
& 25.0 & 62.4 & 99.2 \\
& 50.0 & 88.2 & 101.2 \\
& 100.0 & 139.8 & 102.2 \\
& 150.0 & 191.4 & 102.5 \\
& 170.0 & 209.3 & 101.0 \\
Urine pool & 200.0 & 240.0 & 101.2 \\
& - & 300 & - \\
& 240 & 544 & 101.7 \\
& 275 & 586 & 104.0 \\
& 315 & 607 & 97.5 \\
& 504 & 826 & 104.4 \\
\hline
\end{tabular}

\section{Precision}

We assessed assay precision by replicate analysis of various human serum and urine pools at different phosphate concentrations. Table 2 shows the results obtained.

\section{Method comparison}

We explored the correlation between the enzymatic colorimetric method and two chemical methods, the phosphomolybdate UV method and the molybdenum blue method, in routine serum and urine assays. Results were processed by least-square regression analysis (13); correlation plots and statistical parameters are shown in figures 3 and 4.

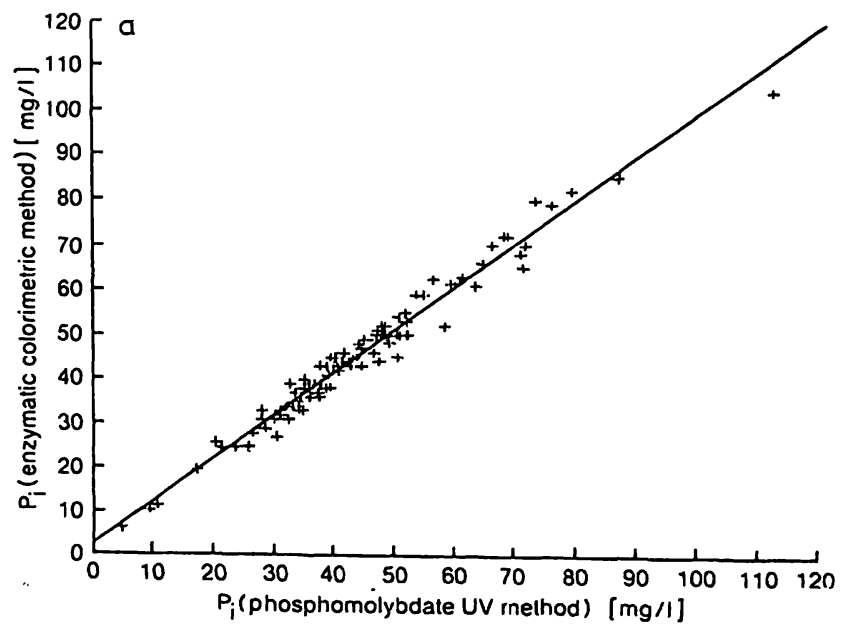

Tab. 2. Precision data

\begin{tabular}{|c|c|c|c|c|c|}
\hline \multicolumn{3}{|l|}{ Serum } & \multicolumn{3}{|l|}{ Urine } \\
\hline $\begin{array}{l}\text { Mean } \\
(\mathrm{mg} / \mathrm{l})\end{array}$ & $\begin{array}{l}\mathrm{SD} \\
(\mathrm{mg} / \mathrm{l})\end{array}$ & $\begin{array}{l}\text { CV } \\
(\%)\end{array}$ & $\begin{array}{l}\text { Mean } \\
(\mathrm{mg} / \mathrm{l})\end{array}$ & $\begin{array}{l}\text { SD } \\
(\mathrm{mg} / \mathrm{l})\end{array}$ & $\begin{array}{l}\text { CV } \\
(\%)\end{array}$ \\
\hline \multicolumn{3}{|c|}{ Within-run $(n=10)$} & \multicolumn{3}{|c|}{ Within-run $(n=12)$} \\
\hline $\begin{array}{l}22.0 \\
38.8 \\
90.0\end{array}$ & $\begin{array}{l}1.00 \\
0.60 \\
1.50\end{array}$ & $\begin{array}{l}4.54 \\
1.55 \\
1.67\end{array}$ & $\begin{array}{r}903.6 \\
1424.6\end{array}$ & $\begin{array}{l}19.1 \\
21.9\end{array}$ & $\begin{array}{l}2.11 \\
1.54\end{array}$ \\
\hline \multicolumn{3}{|c|}{ Between-rụn $(n=12)^{a}$} & \multicolumn{3}{|c|}{ Between-run $(\hat{n}=12)^{a}$} \\
\hline $\begin{array}{l}40.7 \\
51.5 \\
80.0\end{array}$ & $\begin{array}{l}1.00 \\
1.70 \\
2.20\end{array}$ & $\begin{array}{l}2.45 \\
3.30 \\
2.75\end{array}$ & $\begin{array}{l}216.0 \\
508.1 \\
630.0\end{array}$ & $\begin{array}{r}5.5 \\
15.1 \\
10.5\end{array}$ & $\begin{array}{l}2.55 \\
2.97 \\
1.67\end{array}$ \\
\hline
\end{tabular}

a over a 15-day period

\section{Interferences}

We explored the effects of known potential interferents in Trinder-type reactions, either endogenous or exogenous (bilirubin, haemoglobin, ascorbic acid, drugs such as $L$-dopa and its metabolite 3,4-dihydroxyphenylacetate, and $\alpha$-methyldopa), by spiking pooled human sera at normal inorganic phosphorus concentration with known amounts of these substances (for haemoglobin we used washed and lysed erythrocytes). We also tested the effect of hypoxanthine and xanthine, since these occur in the reaction:

Allopurinol was tested as a known inhibitor of xanthine oxidase. The effect on test results of some representative organic phosphates, as well as of the more commonly used anticoagulants, was evaluated simi-

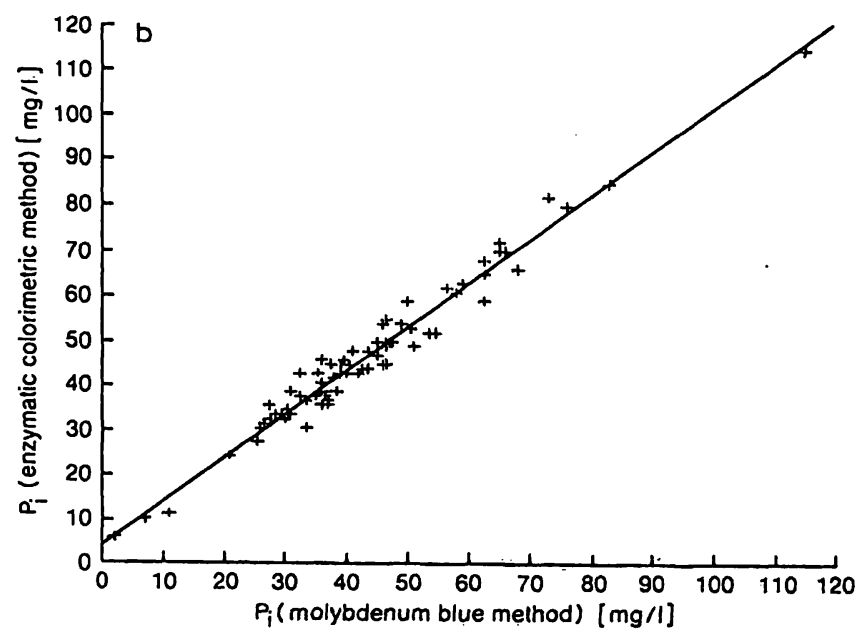

Fig. 3. Correlation plots for serum samples. Regression parameters are for

a) enzymatic colorimetric method $(y)$ vs phosphomolybdate UV method $(x)$ : $\mathrm{y}=0.949 \mathrm{x}+2.6 ; \mathrm{r}=0.985 ; \mathrm{S}_{\mathrm{yx}}=2.8 ; \overline{\mathrm{x}}=44.2 ; \overline{\mathrm{y}}=44.5 ; \mathrm{n}=98$

b) enzymatic colorimetric method $(y)$ vs molybdenum blue method $(x)$ : $y=0.969 x+3.8 ; r=0.983 ; S_{y x}=3.1 ; \bar{x}=43.0 ; \bar{y}=45.5 ; n=75$ 

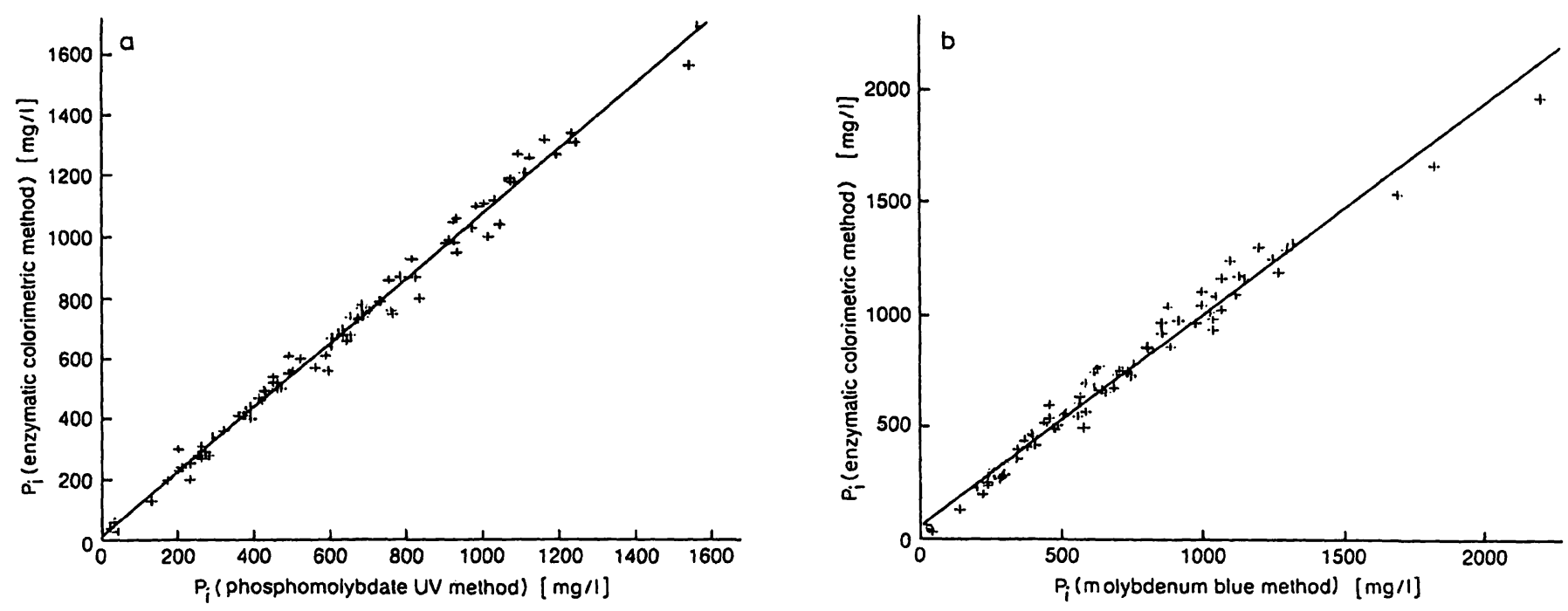

Fig. 4. Correlation plots for urine samples. Regression parameters are for

a) enzymatic colorimetric method $(y)$ vs phosphomolybdate UV method (x):

$\mathrm{y}=1.06 \mathrm{x}+17.3 ; \mathrm{r}=0.995 ; \mathrm{S}_{\mathrm{yx}}=35.9 ; \overline{\mathrm{x}}=660.8 ; \bar{y}=719.2 ; \mathrm{n}=123$;

b) enzymatic colorimetric method $(y)$ vs molybdenum blue method $(x)$ :

$\mathrm{y}=0.958 \mathrm{x}+53.9 ; \mathrm{r}=0.989 ; \mathrm{S}_{\mathrm{yx}}=58.6 ; \overline{\mathrm{x}}=709.4 ; \bar{y}=733.6 ; \mathrm{n}=121$.

larly. Results were assessed by analysing aliquots of pools with and without the interferent in ten replicates; means \pm 3 SD were calculated and values outside this range were taken to indicate interference. No interference was found for concentrations as great as those shown in table 3.

\section{Reference intervals}

The reference limits, 2.5 th -97.5 th percentiles $(0.90$ confidence intervals) for serum inorganic phosphorus were: $24(22-26)-45(43-46) \mathrm{mg} / \mathrm{l}$. For urine spec-

Tab. 3. Results of interference tests

Substance tested

No interference up to

\section{Metabolites}

Bilirubin

Haemoglobin

Hypoxanthine

Xanthine

Adenosine-5-triphosphate

Creatine phosphate

Fructose-1,6-bisphosphate

Glycerol-2,3-bisphosphate

Phosphoenolpyruvate

\section{Drugs}

Ascorbic acid

$L$-Dopa

3,4-Dihydroxyphenylacetate

$\alpha$-Methyldopa

Allopurinol

\section{Anticoagulants}

Disodium EDTA

Sodium heparinate

Sodium citrate

Sodium fluoride

Sodium oxalate

$150 \mathrm{mg} / 1$
$1000 \mathrm{mg} / \mathrm{l}$
$1 \mathrm{mmol} / 1$
$2 \mathrm{mmol} / 1$
$1 \mathrm{mmol} / 1$
$1 \mathrm{mmol} / 1$
$1 \mathrm{mmol} / 1$
$1 \mathrm{mmol} / 1$
$1 \mathrm{mmol} / 1$

$100 \mathrm{mg} / 1$
$20 \mathrm{mg} / 1$
$80 \mathrm{mg} / 1$
$40 \mathrm{mg} / 1$
$2000 \mathrm{mg} / 1$

$2000 \mathrm{mg} / 1$
$500 \mathrm{kilo}-$ USP units/l
$4000 \mathrm{mg} / 1$
$4000 \mathrm{mg} / 1$
$4000 \mathrm{mg} / 1$

imens the reference limits $(x \pm 2 S D)$ were $134-1320$ $\mathrm{mg} / 24 \mathrm{~h}$, with a mean value of $727 \mathrm{mg} / 24 \mathrm{~h}$.

Values for the two sexes did not show a statistically significant difference ( $t$-test, $p>0.05$ ).

\section{Control sera}

We ran tests on several control sera from different sources. The values obtained and the claimed control sera values are shown in table 4 . It should be pointed out that large differences exist among the claimed values by the different chemical methods; therefore the two extreme assay values (and the overall acceptable ranges) are given in the table.

Tạb. 4. Results with control sera

\begin{tabular}{|c|c|c|}
\hline \multirow{2}{*}{$\begin{array}{l}\text { Control serum } \\
\text { and Lot No. }\end{array}$} & \multicolumn{2}{|c|}{ Inorganic phosphorus (mg/l) } \\
\hline & Claimed (range) & $\begin{array}{l}\text { Present } \\
\text { method }\end{array}$ \\
\hline Mọnitrol I-E, LTD-205 & $39.2-42.1(36.2-45.0)$ & 40.3 \\
\hline Monitrol II-E, PTD-103 & $74.5-77.8(68.5-83.2)$ & 79.1 \\
\hline Precinorm U, 1-588 & $52.6-57.2(45.2-65.2)$ & 54.3 \\
\hline Precilip, 1-375 & $33.4-41.2(28.7-43.7)$ & 35.8 \\
\hline Validate, 3268022 & $34.4-36.5(29.4-40.3)$ & 40.3 \\
\hline Validate, 4333112 & $29.0-33.0(27.0-35.0)$ & 32.2 \\
\hline Validate A, 3725102A & $61.0-68.0(52.0-87.0)$ & 69.0 \\
\hline Wellcomtrol N, K7475 & $38.4 \quad(37.2-40.3)$ & 40.5 \\
\hline Ortho Normal, 020A01 & $35.0-44.0(25.0-48.0)$ & 38.0 \\
\hline Ortho Abnormal, 025A01 & $66.0-75.0(59.0-83.0)$ & 79.3 \\
\hline Roche N, P1833 & $33.5-34.0(30.5-37.0)$ & 36.3 \\
\hline Kontrollogen L, 623122K & $40.5-45.0(36.0-51.0)$ & 44.8 \\
\hline Kontrollogen LP, 623208 & $70.5-72.0(60.0-81.0)$ & 79.5 \\
\hline Seronorm, 159 & $34.4-37.2(32.5-39.3)$ & 38.3 \\
\hline Biotrol N, 559 & $48.0-56.0(45.0-59.0)$ & 56.1 \\
\hline Biotrol P, 707 & $78.0-84.0(74.0-90.0)$ & 93.1 \\
\hline Q-Pak I, N41B & $30.0-35.0(27.0-38.0)$ & 28.1 \\
\hline Q-Pak II, P32B & $66.0-71.0(61.0-77.0)$ & 72.0 \\
\hline
\end{tabular}




\section{Discussion}

Existing chemical methods for assaying inorganic phosphorus in biological fluids generally lack sufficient specificity and ease of execution - two main considerations for routine use. The method at issue is highly specific and easy to perform, being based on an appropriate enzymatic reaction coupled with a sensitive colorimetric measurement.

Method linearity (up to at least $240 \mathrm{mg} / \mathrm{l}$ ) is broad enough to make reassays unnecessary. Owing to the high sensitivity, precision is very good at the various phosphate levels tested, including the low ones. Comparative studies versus the phosphomolybdate UV method and the molybdenum blue method showed good agreement for both serum and urine.

High bilirubin and ascorbic acid concentrations, as well as moderate haemolysis do not affect results; haemoglobin above $1 \mathrm{~g} / \mathrm{l}$ causes increased absorption and leads to phosphorus overassay.

Endogenous hypoxanthine and xanthine might interfere by generating stoichiometric amounts of hydrogen peroxide; but they are neutralized in the two-step procedure by reaction with $\mathrm{N}$-ethyl-N-(3-methylphenyl)- $\mathrm{N}^{\prime}$-acetylethylenediamine during preincubation, forming a colourless product in the absence of inosine and 4-aminophenazone.

\section{References}

1. Weissman, N. \& Pileggi, V. J. (1974) Inorganic Ions: Phosphate in Clinical Chemistry: Principles and Technics, 2nd edn. (Henry, R. J., Cannon, D. C. \& Winkelmann, J. W., eds.) pp. 720-728, Harper \& Row, Hagerstown.

2. Schulz, D. W., Passonneau, J. V. \& Lowry, O. H. (1967) Anal. Biochem. 19, 300-314.

3. Pesce, A. M., Bodourian, S. H. \& Nicholson, J. F. (1974) Clin. Chem. 20, 332-336.

4. Scopes, R. K. (1972) Anal. Biochem. 49, 88-94.

5. Hwang, W. I. \& Cha, S. (1973) Anal. Biochem. 55, 379387.

6. Fossati, P. (1985) Anal. Biochem. 149, 62-65.

7. Machida, Y. \& Nakanishi, T. (1982) Agric. Biol. Chem. 46, 807-808.

8. Colombi, M., Bosoni, A., Fossati, P. \& Musitelli, C. (1985) Isr. J. Clin. Biochem. 4, 31 (Abstract).

9. Berti, G., Fossati, P., Melzi d'Eril, G. V., Tarenghi, G. \& Musitelli, C. (1987) Clin. Chem. 33, 312 (Technical Brief).
No interference from these oxypurines was seen with concentrations in excess of values ever found in serum (14). It should, however, be noted that even in the one-step procedure the results are affected only at very high values, such as those of patients receiving allopurinol (15). Allopurinol showed no inhibitory effect of its own. For $L$-dopa and $\alpha$-methyldopa, a borderline negative interference may occur; no interference from 3,4-dihydroxyphenylacetate was noted. Organic phosphates with relatively high free energy of hydrolysis $(\geq 21 \mathrm{~kJ} / \mathrm{mol} \cong \geq 5.0 \mathrm{kcal} / \mathrm{mol})$ are easily degraded in an acidic medium and are reported to interfere more or less significantly in chemical assay methods for inorganic phosphate (1). We tested a variety of phosphate links (ester, acetal, phosphoric acid anhydride, and amidophosphate) and found that none would interfere in the present method, even at concentrations much higher than those found in serum (16) or likely to be released by moderate haemolysis. Anticoagulants did not interfere.

In conclusion the method discussed in this paper shows good sensitivity, linearity and precision. With respect to accuracy, the method offers the advantage over chemical procedures of being free of interference from organic phosphate. Added advantages are the use of noncorrosive reagents, ease of handling, and adaptability to clinical laboratory instruments.

10. Daly, J. A. \& Ertingshausen, G. (1972) Clin. Chem. 18, 263-265.

11. Power, M. H. (1953) in Standard Methods of Clinical Chemistry I (Reiner, M., Ed.) pp. 84-87, Academic Press, New York.

12. Solberg, H. E. (1983) J. Clin. Chem. Clin. Biochem. 21, $749-760$.

13. Westgard, J. O. (1973) Clin. Chem. 19, 49-57.

14. Hande, K. E., Perini, F., Putterman, G. \& Elin, R. (1979) Clin. Chem. 25, 1492-1494 (Case Report).

15. Kito, M., Tawa, R., Takeshima, S. \& Hirose, R. (1982) J. Chromatog. 231, 183-188.

16. Natelson, S. \& Natelson, E. A. (1975) Mechanisms Controlling Serum Phosphate Levels in Principles of Applied Clinical Chemistry, 1, pp. 169-174, Plenum Press, New York.
Dr. Giovanni Berti

Laboratorio Ricerca \& Sviluppo

Miles Italiana SpA, Div. Ames

Via F. L. Miles 10

I-20040 Cavenago Brianza (Milano) 